\title{
Początki zainteresowań problematyką klimatu organizacyjnego w polskiej literaturze naukowej
}

\author{
Autor: Grzegorz Wudarzewski
}

\begin{abstract}
Abstrakt
Artykuł zawiera chronologiczny przegląd początków polskiego dorobku naukowego poświęconego problematyce zjawiska klimatu organizacyjnego. Autor przedstawił prace pierwszych polskich badaczy tego pojęcia, a następnie scharakteryzował proponowane przez nich koncepcje, definicje, typologie, wymiary i składniki oraz kierunek badań wraz z ich zakresem, wnioskami i osiągniętymi rezultatami. W dalszej części autor dokonał podsumowania i usystematyzowania dorobku pierwszych polskich badaczy, skonfrontował osiągnięcia pierwszych polskich badaczy klimatu z dorobkiem zagranicznym, a następnie wskazał potencjalne kierunki rozważań i badań naukowych nad klimatem organizacyjnym.
\end{abstract}

Słowa kluczowe: klimat organizacyjny, klimat społeczny, typy klimatu organizacyjnego, wymiary i składniki klimatu organizacyjnego, czynniki wpływające na klimat organizacyjny

\section{Wstęp}

Wątek klimatu organizacyjnego stanowi ważny element zainteresowań związanych z wybranymi aspektami motywacji pracowniczej, procesów zarządzania i kierowania, a także opinii, ocen i odczuć pracowniczych dotyczących warunków panujących w miejscu pracy. Nawiązanie do wskazanych obszarów wyraźnie uwypukla znaczenie pojętej problematyki w kontekście zainteresowań czynnikiem ludzkim w organizacji. W porównaniu z wieloletnim
JEL: M12, M50

Historia: otrzymano 2015-09-02, poprawiono 2016-02-20, zaakceptowano 2016-02-20

dorobkiem zagranicznym w tym zakresie, który jest dosyć obszerny, wielowątkowy, a także względnie skrystalizowany i usystematyzowany, polski dorobek naukowy w tej kwestii traktowany jest jako nurt bardziej uboczny, powiązany z takimi wiodącymi tematami, jak choćby kultura organizacyjna, kierowanie ludźmi czy motywowanie, a ponadto zainteresowania z nim związane mają charakter dosyć fragmentaryczny i są mniej usystematyzowane. Na taki stan złożyło się wiele przyczyn, ale jednym z ważniejszych czynników 
ukształtowania się takiej sytuacji był z pewnością bardziej ograniczony niż obecnie dostęp do znaczących publikacji zagranicznych (przede wszystkim anglojęzycznych, chociaż nie tylko) poświęconych problematyce klimatu organizacyjnego, zwłaszcza w okresie drugiej połowy XX wieku. Chodzi tutaj przede wszystkim o ograniczenia związane z zakresem funkcjonalności i stopniem zaawansowania rozwiązań informatycznych, które utrudniały pozyskiwanie niezbędnych i aktualnych materiałów, analizowanie baz danych w bibliotekach elektronicznych, a także wymianę doświadczeń, opinii i poglądów z kluczowymi autorytetami i specjalistami w różnych częściach świata w tym obszarze oraz interaktywnego konsultowania z nimi różnych wątpliwości i kwestii spornych. W rezultacie do roku 2000 opublikowano w Polsce mało opracowań naszych rodzimych badaczy, które dodatkowo bazowały na względnie skromnej bazie wiodących, choć dużo wcześniejszych pozycji zagranicznych. Powszechnym zjawiskiem w tym okresie było także wzajemne dublowanie i przywoływanie $w$ polskich publikacjach dosyć skromnej i częściowo przedawnionej bazy źródeł naukowych. Doprowadziło to do opóźnień ujęć naukowych problematyki klimatu organizacyjnego. Początek XXI wieku charakteryzuje się wzrostem zainteresowań omawianej problematyki w skali międzynarodowej, co przekłada się także na znaczący wzrost dociekań, badań i publikacji polskich w tym zakresie. Tendencjom tym sprzyjał także ogromny rozwój rozwiązań informatycznych oraz postępująca globalizacja społeczno-gospodarcza. Powstałe jednak wcześniej opóźnienia w obszarze naukowym powiązanym z klimatem organizacyjnym nie były łatwe do szybkiego nadrobienia i wymagają dalszych wysiłków. W opinii autora wciąż występuje $w$ tym zakresie pewna luka teoretyczna, którą warto bliżej rozpoznawać i wypełniać.
W szczególności dotyczy to niedostatków odnoszących się do konceptualizacji i systematyzacji opisywanej problematyki. Niektóre wątki i problemy naukowe związane ze zjawiskiem klimatu, dostrzegane i w zasadzie rozwiązane we wcześniejszym dorobku zagranicznym, $w$ dalszym ciągu pojawiają się w naszych rodzimych dociekaniach badawczych, a część wcześniejszych rozwiązań i propozycji nie jest w ogóle dostrzegana i uwzględniana ${ }^{1}$. Warto podkreślić, że sygnalizowane niedostatki teoretyczne mogą ograniczać rozwój naukowy metodyki diagnozowania klimatu organizacyjnego oraz efektywność aplikacji z tym związanych. W przekonaniu autora, warto zaangażować się $w$ wypełnienie istniejącej luki teoretycznej, występującej w polskim dorobku naukowym w odniesieniu do klimatu organizacyjnego. Ze względu na szeroki zakres czasowy i merytoryczny podjętego tematu, autor zdecydował się rozdzielić swoje rozważania w tym zakresie na dwa opracowania. Pierwsze z nich jest poświęcone przybliżeniu i usystematyzowaniu początkowych zainteresowań klimatem organizacyjnym w dorobku polskim do końca lat 90., natomiast kolejne opracowanie będzie poświęcone systematyzacji polskiego dorobku naukowego $\mathrm{w}$ tym zakresie do lat współczesnych ${ }^{2}$.

\footnotetext{
$\overline{1}$ Zagrożeniem dla takiej sytuacji może być ponowne odsunięcie przez polskich naukowców rozważań nad klimatem na dalszy plan, wynikające $\mathrm{z}$ niepełnego zrozumienia i znajomości tego zjawiska bądź też brakiem systematyzacji i odniesienia konstruktu klimatu w stosunku do powiązanych z nim pojęć, takich jak chociażby kultura organizacyjna, satysfakcja i zadowolenie pracownicze czy morale pracowników.

2 Prezentowana publikacja stanowi cząstkowy wynik szerokich zainteresowań autora problematyką klimatu organizacyjnego. Autor jest w trakcie przygotowywania obrony pracy doktorskiej pt. „Metodyka badania klimatu organizacyjnego w przed-
} 
Celem niniejszego opracowania jest chronologiczny przegląd początków polskiego dorobku naukowego poświęconego problematyce zjawiska klimatu organizacyjnego oraz próba jego systematyzacji w odniesieniu do proponowanych koncepcji, definicji, typologii, wymiarów i składników klimatu organizacyjnego, a także kierunku podejmowanych badań wraz z ich zakresem, wnioskami i osiągniętymi rezultatami.

\section{Pierwsze publikacje polskie poświęcone problematyce klimatu organizacyjnego w latach} 60. i 70. XX wieku

Znaczenie uwarunkowań psychosocjologicznych w funkcjonowaniu organizacji zaczęto dostrzegać i przybliżać bardzo wcześnie. Początkowo jednak w podejmowaniu problematyki klimatu organizacyjnego nie posługiwano się wprost kategorią klimat organizacyjny, chociaż wyraźnie nawiązywano do istoty i znaczenia tego zjawiska. Już pierwsi klasycy dyscyplin naukowych traktujących o zarządzaniu wyraźnie dostrzegali i podkreślali pośrednio kwestie z klimatem organizacyjnym, najpierw zaczepnie, a później już bardzo wyraźnie, w ramach wyodrębnionej szkoły stosunków międzyludzkich w rozwoju naukowym zarządzania. Na uwagę zasługują w tym świetle pamiętne i w pewnym sensie prorocze elementy dorobku naszego rodaka, Karola Adamieckiego (1863-1933), wybitnego prekursora naukowego zarządzania, odnoszące się do prawa harmonii duchowej w organizacjach jako trzeciego, niezbędnego składnika zasady harmonizacji (obok prawa harmonii doboru i prawa harmonii działania), wyrażające się w słowach: „na kierownikach (...) leży obowiązek rozbudzania w podwładnych mu

siębiorstwie. Adaptacja i wykorzystanie." Przewidywany termin obrony - początek 2015 r. organach ducha współpracy i podtrzymywania harmonii duchowej, bez czego trzecie zasadnicze prawo ekonomii doboru i działania nie będzie mogło być zastosowane w całej pełni" (Adamiecki 1985). Powszechnie znane są również doświadczenia i konkluzje wynikające z badań eksperymentów przeprowadzonych pod kierunkiem Eltona Mayo, najpierw w Filadelfii 1922 r., a w kolejnych latach w Hawthorne, które pozwoliły wyodrębnić ważną grupę czynników psychosocjologicznych, wpływających na wydajność pracy. W opinii badaczy powiązanych z przywoływanymi eksperymentami udało się wtedy połączyć wreszcie tzw. logikę wydajności i logikę uczuć (Martyniak 1996). W kolejnych latach dociekania naukowe powiązane z klimatem organizacyjnym utożsamiano z tzw. klimatem społecznym i klimatem emocjonalnym (Lewin i in. 1939; Burnside i in. 1988). Pierwsze publikacje anglojęzyczne, w których stosowano bezpośrednio termin „klimat organizacyjny", ukazały się jeszcze w latach 50. ubiegłego wieku, chociaż wyraźny wzrost zainteresowań tym zjawiskiem miał miejsce w latach 60. W 1955 r. Francis Cornell, opisując problematykę nastrojów i zachowań w środowiskach szkolnych, prawdopodobnie jako jeden z pierwszych badaczy stosuje termin „klimat organizacyjny” (Cornell 1955). Przywoływany badacz postrzega to zjawisko jako zbiór interpretacji i odczuć ludzi w stosunku do innych członków organizacji, podkreślając jednocześnie rolę percepcji uczestników organizacji jako najbardziej znaczącego czynnika determinującego poziom klimatu.

W piśmiennictwie polskim terminem „klimat” w kontekście uwarunkowań organizacyjnych posługuje się Sokołowski w 1967 roku, sugerując „potrzebę stworzenia w Hucie (organizacji) klimatu, w którym wszyscy pracownicy mogliby skutecznie wykrywać rezerwy i poszukiwać nowych pomysłów twórczych (Sokołowski 1967). Chociaż 
artykuł wskazanego autora nie ma charakteru naukowego $z$ obszaru problematyki organizacji i zarządzania, to jednak zastosowanie terminu "klimat" w kontekście tej problematyki może świadczyć o względnie powszechnym posługiwaniu się i rozumieniu pojęcia klimat, na co w kolejnych latach zwrócił uwagę inny polski badacz, Baran, wskazany w dalszej części niniejszej publikacji. Prawdopodobnie pierwsza polska publikacja naukowa, w której wprost zastosowano termin „klimat organizacyjny” i szerzej rozwinięto istotę tego zjawiska, ukazała się $w$ drugiej połowie lat 70 . i była autorstwa Dobrzyńskiego, w której badacz przedstawił rozważania na temat zależności pomiędzy klimatem organizacyjnym a stylami kierowania-zarządzania (Dobrzyński 1977). Opierając się na pracach McClellanda, Lewina, Blake'a i Mouton, polski badacz określił konstrukt klimatu jako ogół stosunków społecznych, kształtujących zachowania pracownicze $w$ zakładzie pracy, będący pod wpływem takich warunków funkcjonowania instytucji, jak formalna struktura organizacyjna, sposób przebiegu informacji, sytuacja ekonomiczna, typ technologii, wymagania wobec organizacji stawiane przez otoczenie i interesariuszy czy też interesy i dążenia-motywy poszczególnych pracowników grup roboczych. $\mathrm{Na}$ tej podstawie przywoływany badacz wskazał i opisał cztery potencjalne typy klimatu, których wyłonienie może być związane z charakterem potrzeb uczestników organizacji występujących w danym okresie:

1. Klimat biurokratyczny, wynikający z potrzeby bezpieczeństwa, uwzględniający stabilne reguły postępowania, pogłębienie procesu formalizacji instytucji.

2. Klimat autorytarny, oparty na silnej władzy osobistej kilku osób obejmujących kluczowe stanowiska, niekoniecznie działających w oparciu o obowiązujące reguły i nie wymagających tego od podwładnych, oceniających podwładnych głównie za osiągane wyniki.

3. Klimat innowacyjny - wpływy pracownicze opierają się na kwalifikacjach fachowych, silna orientacja na rozwój organizacyjny i samodzielny rozwój pracowników, elastyczny charakter pracy, tendencja do tworzenia czasowych zespołów, które mają zmierzyć się z wyzwaniem organizacyjnym.

4. Klimat towarzyski, będący rezultatem dążenia pracowników do zachowania dobrych stosunków koleżeńskich, zintegrowanego zespołu, uwzględniania interesów pracowników. Przy tym typie klimatu cele organizacji mogą się stać kwestią drugorzędną.

\section{Polski dorobek naukowy poświęcony klimatowi organizacyjnemu w latach 80. XX wieku}

W latach 80. stopniowo wzrasta zainteresowanie naukowe związane ze zjawiskiem klimatu organizacyjnego. W roku 1980 Mirosław Wyciślak podkreśla i naświetla różnorodność interpretacji tego zagadnienia, wskazując na: a) utożsamianie klimatu z koncepcją kultury, b) rozpatrywanie klimatu jako „prestiżu organizacji” oraz c) skojarzenie klimatu z metaforą „osobowości organizacji” (Wyciślak 1980). Polski badacz, bazując na wskazanych wcześniej propozycjach Dobrzyńskiego, zdefiniował klimat organizacyjny jako główny czynnik kształtujący zachowania organizacyjne pracowników, wynikający z treści stosunków społecznych obejmujących warunki funkcjonowania instytucji - formalnej struktury władzy, typu technologii, wymagań stawianych organizacji, motywów-dążeń i interesów pracowników i zespołów pracowniczych. Jednocześnie Wyciślak zaznaczył, że podstawą tworzenia i kształtowania się zjawiska 
klimatu mogą być zarówno czynniki obiektywne, jak też subiektywne, a samo pojęcie może być rozpatrywane jako zmienna zależna bądź niezależna. W dalszej części publikacji, wykorzystując dorobek naukowy m.in. Litwina, Stringera Tagiuri, Forehanda, Taylora, Hellriegle'a, Morse'a, Payne'a, Pritcharda, Karasicka i Steersa, odnoszący się do klimatu organizacyjnego, badacz przedstawił potencjalne składniki i charakterystyki klimatu. W końcowej części Wyciślak zaproponował i opisał model roli klimatu w funkcjonowaniu organizacji, obejmujący współzależności i sprzężenia zwrotne między cechami charakterystycznymi organizacji, możliwe percepcje sytuacji organizacyjnej, a także motywacje, zachowania i skutki dla motywacji.

Rozważania i propozycje Wyciślaka i Dobrzyńskiego na temat klimatu organizacyjnego były kontynuowane i rozwijane w kolejnej publikacji pierwszego ze wskazanych badaczy, który wspólnie z Mariuszem Bratnickim przedstawił zarys problematyki konceptualizacji i kierunków badań oraz sposób mierzenia i diagnozowania klimatu organizacyjnego (Bratnicki Wyciślak 1980). Przyjęta przez autorów definicja klimatu wyraźnie koresponduje z wcześniejszymi propozycjami Dobrzyńskiego i Wyciślaka, i ostatecznie klimat organizacyjny opisano jako zbiór względnie trwałych cech charakterystycznych sytuacji organizacyjnych i skutków społecznych funkcjonowania organizacji, subiektywnie postrzeganych przez uczestników i kształtujących motywy zachowań pracowniczych. Podkreślono także obiektywno-subiektywny charakter zjawiska klimatu organizacyjnego, kojarzonego $\mathrm{z}$ atmosferą panującą $w$ organizacji oraz jego względną odrębność od zjawiska zadowolenia z pracy. Bratnicki i Wyciślak zaproponowali w swojej publikacji 41 potencjalnych składników klimatu, wskazując na częstotliwość ich przywoływania przez różnych badaczy; przedstawili także możliwość traktowania klimatu organizacyjnego jako zmiennej zależnej, niezależnej lub pośredniczącej. W opinii wskazanych badaczy użyteczność klimatu organizacyjnego może się odnosić do m.in. do: identyfikowania i wyjaśniania zjawisk oraz problemów, które zwykle są trudno dostrzegalne i ukryte pod powierzchnią zachodzących procesów oraz zachowań dotychczas niezauważonych, dostrzegania i analizy wzajemnych relacji między klimatem a innymi występującymi w obszarze organizacji i zarządzania, a także do formułowania wniosków i wskazywania kierunków usprawniających funkcjonowanie organizacji. W końcowej części publikacji przedstawiono wyniki diagnozy klimatu organizacyjnego przeprowadzonej w roku 1979 na próbie 80 kierowników kadry kierowniczej jednego z polskich zjednoczeń o charakterze usługowym. Dobór składników klimatu organizacyjnego zastosowanych w badaniach diagnostycznych poprzedzono wstępnym rozpoznaniem organizacji i konsultacjami z kierownictwem, wykorzystując $w$ tym zakresie przytoczone w artykule pozycje literaturowe i propozycje w nich zawarte.

W roku 1981 Dobrzyński zwrócił uwagę, że pojęcie klimatu organizacyjnego jest czymś więcej niż sumą wartości uznawanych przez członków organizacji, ponieważ stanowi zbiorową świadomość percepcyjną odnośnie pożądanego sposobu postępowania (Dobrzyński 1981). Wśród wewnętrznych uwarunkowań organizacyjnych badacz wskazał bezpośrednie interakcje między ludźmi, pośrednictwo w podziale zadań, technologię, a także sposób wykonywania pracy, które łącznie tworzą i kształtują swoistą interakcję zadaniową. W opinii przywoływanego badacza systematykę charakteru interakcji występujących w tym zakresie można wykorzystać jako podstawę klasyfikacji różnych odmian klimatu organizacyjnego. W tym kontekście 
Dobrzyński zaproponował i scharakteryzował sześć typów klimatu:

1. Klimat autokratyczny - wartościami szczególnie cenionymi w organizacji są wpływy osobiste, umiejętności fachowe, uległość i lojalność wobec osób wpływowych. Lekceważone są z kolei reguły formalne. Szanse na rozwój i awans mają ci pracownicy, którzy zostali zakwalifikowani przez wpływowych ludzi jako wartościowi.

2. Klimat liberalny - dążenie pracowników do akceptacji przez innych, utrzymywanie poprawnych stosunków i unikanie konfliktów. Kluczowym czynnikiem podejmowania decyzji jest unikanie działań na szkodę jej członków i grupy jako całości. Informacje przebiegają w sposób nieformalny i mogą dotyczyć osobistych spraw członków organizacji.

3. Klimat biurokratyczny - przestrzeganie reguł formalnych i zasad realizacji zadań. Proces decyzyjny ogranicza się do wyboru adekwatnej procedury, czasem wcześniej określonej, dla danego zadania bądź sytuacji. Zasady zarządzania dotyczą przyswojenia przepisów i znajomości zasad funkcjonowania organizacji.

4. Klimat technokratyczny - charakteryzuje się możliwością inicjatywy, wykorzystania kwalifikacji, wiedzy fachowej. Uznanie otrzymuje się za wykonywanie zadań ambitnych, stanowiących wyzwanie. W kontekście tego typu zadań może wystąpić tendencja do formowania zespołów zadaniowych, projektowych bądź rozwiązywania problemów.

5. Klimat anarchiczny - słabo zintegrowany układ o rozluźnionych więziach organizacyjnych.

6. Klimat demokratyczny - wysoki stopień zorganizowania, interakcje przełożony-podwładny oparte są na autorytecie rzeczywistym, wzajemnym partnerstwie i respektowaniu godności osobistej, reguły mają na celu poprawę pracy twórczej i rozwój, i nie są postrzegane jako ograniczenie.

Polski badacz zasygnalizował także potrzebę dostosowania strategii firmy do panującego klimatu organizacyjnego, przestrzegając, że niedostatki w tym zakresie mogą obniżyć efektywność działań i być przyczyną niepowodzeń.

W roku 1983 Józef Baran opisał problematykę stosunków międzyludzkich i klimatu społecznego w socjalistycznym zakładzie pracy i chociaż posiłkował się terminem "klimat społeczny”, to jednak kontekst i charakterystyka tego pojęcia wyraźnie nawiązywały do koncepcji klimatu organizacyjnego (Baran 1983). Baran zwrócił uwagę, że termin "klimat społeczny" był dość często stosowany w ówczesnym i wcześniejszym języku potocznym i odnosił się do szerszych warstw społecznych i zachodzących w nich wydarzeń, rodzaju działań bądź też rozwiązywania problemów i spraw spornych, mimo niewielkiego ówczesnego dorobku naukowego (w warunkach polskich) w tym zakresie. Polski badacz podkreślit, że $\mathrm{w}$ potocznym rozumieniu klimat społeczny stosowany był jako synonim słowa "warunek" - czynnik, od którego zależy powodzenie i skuteczność ludzkich działań, ale - jak sam zauważył - pojęcie to spełnia dodatkowo szereg innych funkcji w życiu społeczno-zawodowym. Ponadto zauważył, że problematyka klimatu i stosunków społecznych była w tamtym okresie marginalizowana, o czym świadczyła niewielka ilość publikacji poświęcona temu zagadnieniu oraz jedynie zaczepny i fragmentaryczny charakter pojawiających się dociekań naukowych. We wskazanej publikacji klimat społeczny opisany został jako zbiór, splot zjawisk, procesów i czynników psychologicznych, społecznych i kulturowych (nastroje, emocje, formy 
i zasady odnoszenia się do siebie, uzewnętrznianie odczuć i postaw, sposoby prezentowania i manifestowania swoich poglądów przez poszczególne jednostki, kryteria ocen, uznawane wartości, wewnątrzzakładowa obyczajowość itd.), występujących i funkcjonujących w środowisku pracy. Klimat społeczny można według polskiego badacza rozumieć jako swoisty duch pracy ludzkiej, duch życia i działalności społeczno-zawodowej oraz kulturalnej człowieka w środowisku pracy, który może być rozpatrywany w kategoriach dobry/zły (klimat). Badacz scharakteryzował wskazane odmiany klimatu w sposób następujący:

1. Dobry klimat - w danym środowisku panują harmonijne, życzliwe stosunki międzyludzkie, sprawiedliwość, wyrozumiałość, tolerancyjność, szczerość, wzajemne zaufanie i zrozumienie, spokój społeczny. Występowanie dobrego klimatu oznacza zadowolenie ludzi z pracy, warunków pracy, panujących stosunków społecznych w organizacji w taki sposób, że jej uczestnicy mogą żyć w spokoju, rozwijać się, działać zgodnie i zaspokajać swoje potrzeby.

2. Zły klimat $-\mathrm{w}$ danym środowisku występuje nieufność, podejrzliwość, tendencyjność i niesprawiedliwość odnosząca się do oceniania, wyróżniania i nagradzania pracowników. Mogą również występować zjawiska zawiści, intryganctwa, oszustwa itd., których rezultatem będą ciągłe napięcia, zła atmosfera, konfliktowość stosunków społecznych czy rozgoryczenie.

Baran wskazuje także najważniejsze czynniki kształtujące ocenę klimatu społecznego, do których zalicza m.in.: a) jakość pracy i warunków pracy; b) stosunki międzyludzkie istniejące w zakładzie pracy, zwłaszcza w odniesieniu do relacji przełożony-podwładny; c) styl kierowania i zarządzania; d) zasady i kryteria oceniania, wynagradzania i awansowania; e) zbiór cech i predyspozycji psychospołecznych samych ludzi. Kolejnym wątkiem poruszonym przez Barana była problematyka wpływu i oddziaływania klimatu na pracę człowieka, rozpatrywana poprzez odniesienie do stosowania metafory zjawisk meteorologicznych. W dalszej części publikacji opisana jest również szczegółowo rola kierownika i jej wpływ na kształtowanie tych pojęć wraz ze wskazaniem rezultatów stylu kierowania autokratycznego i demokratycznego oraz znaczenia autorytetu moralnego i rzeczywistego.

W roku 1984 ukazała się publikacja Barbary Kożusznik i Tomasza Jezierskiego poświęcona problematyce psychologii doskonalenia zespołów (Kożusznik, Jezierski 1984). Zagadnienie klimatu organizacyjnego rozpatrywane było w niej w kontekście efektywności kierowania i stosowania odpowiednich stylów kierowniczych. We wskazanej publikacji pojęcie klimatu zespołowego stosowano zamiennie $z$ klimatem organizacyjnym i traktowano jako zbiór ogólnych właściwości organizacji, mający wpływ na zachowania jednostek i zespołów ludzkich, kształtujący zarazem ich określone właściwości. Odwołując się do wcześniejszego dorobku Lewina, White'a i Lippita, a także klasyfikacji stylów Likerta (autokratyczno-despotycznego i autokratyczno-życzliwego, konsultatywnego, demokratycznego), dwójka polskich badaczy podkreśliła rolę kierownika w kształtowaniu klimatu. Badacze wskazują np., że klimat wytwarzany przy stosowaniu stylu autokratyczno-despotycznego może skutkować m.in. trudnościami w swobodnej komunikacji, marginalizowaniem inicjatywy oddolnej czy oczekiwaniami natychmiastowego wykonywania wydawanych poleceń. Z kolei przywołany dorobek McClellanda czy Bella może sugerować, według Kożusznik i Jezierskiego, że na dobór stylu kierowania, 
budowanie relacji z pracownikami czy w końcu dbałość o klimat organizacyjny, mogą mieć wpływ pewne czynniki i uwarunkowania stanowiące składniki motywacji kierownika. Odpowiedni klimat organizacyjny postrzegany był przez badaczy jako jeden z warunków skutecznego wykorzystania techniki socjometrycznej o charakterze interwencyjnym. Dodatkowo Kożusznik i Jezierski zamieszczają w swojej publikacji narzędzie diagnozy klimatu organizacyjnego. Przedstawiony i opisany kwestionariusz badawczy jest przetłumaczoną na język polski wersją zaproponowaną wcześniej przez Kolba, Rubina i McIntyre'a, którzy z kolei dokonali modyfikacji oryginalnego narzędzia Litwina i Stringera.

W innej publikacji z roku 1988 r., poświęconej problematyce kultury organizacyjnej, Bratnicki wspólnie Romanem Krysiem i Janem Stachowiczem, charakteryzując zagadnienie klimatu, przyjęli jako podstawę rozważań koncepcję i propozycję czterech typów klimatu Dobrzyńskiego, dokonując ich szczegółowego opisu i charakterystyki (Bratnicki i in. 1988). Przywoływani badacze przedstawili wyniki badań przeprowadzonych w trzech wybranych przedsiębiorstwach, których celem była diagnoza 6 typów klimatów-barier: technokratycznej, samoobrony, podporządkowania, konserwatywnej, indywidualizmu i rywalizacyjnej. Badacze wykorzystali w tym zakresie kwestionariusz badawczy złożony z 30 pozycji, zaproponowany przez Argyrisa i Schöna. Wskazywana publikacja jest jednocześnie przykładem problemów występujących w analizowanym okresie, a dotyczących dookreślenia i rozróżnienia konstruktów: klimat organizacyjny i kultura organizacyjna oraz wzajemnych zależności między nimi. Na przykład Bratnicki, Kryś i Stachowicz sugerują w swoim opracowaniu, że różne typy kultury organizacyjnej to $w$ rzeczywistości różne klimaty. $\mathrm{W}$ rozdziałach poświęconych problematyce klimatu organizacyjnego pojęcia kultury i klimatu są w niektórych sytuacjach stosowane zamiennie, a w innych granica między nimi jest tak niewyraźna, że potencjalny czytelnik może mieć wątpliwości odnoszące się do zasadności wyodrębnienia wskazywanych kategorii oraz występujących zależności.

\section{Polski dorobek naukowy poświęcony klimatowi organizacyjnemu w latach 90. XX wieku}

W pierwszej połowie lat 90. wśród polskich badaczy klimatu organizacyjnego wyróżnił się Stanisław Chełpa, który w pracach naukowych Akademii Ekonomicznej we Wrocławiu przedstawił rozważania nad podmiotowością pracowników i przełożeniem jej na problematykę klimatu i efektywności organizacyjnej (Chełpa 1992). Konstrukcja klimatu organizacyjnego została przedstawiona w oparciu o wcześniejsze propozycje Wyciślaka, Bratnickiego, Katza i Kahna oraz Forehanda i Gilmera jako zjawisko niezmienne w czasie, wpływające na zachowania pracowników i odróżniające dane przedsiębiorstwo od innych. W kontekście zaproponowanych przez Dobrzyńskiego pierwszych 4 typów klimatu: biurokratycznego, autoratywnego, towarzyskiego i innowacyjnego Chełpa zwrócił uwagę, że dwa pierwsze typy klimatów mogą $w$ większym stopniu przyczyniać się do alienacji pracowniczej, natomiast dwa ostatnie - do podmiotowości pracowniczej, dodając jednocześnie, że poczucie alienacji/podmiotowości zależy również od dopasowania między typem klimatu a oczekiwaniami i potrzebami człowieka. Według opinii Chełpy oznacza to, że nie ma jednego uniwersalnego typu klimatu - sam typ klimatu nie warunkuje poczucia podmiotowości/alienacji, ale liczy się sposób jego interpretowania przez pracowników, jak również cechy, postawy, dążenia 
i oczekiwania samych pracowników. Wskazany badacz jednakże swój istotny wkład w polski dorobek z zakresu klimatu organizacyjnego zaznaczył w kolejnej publikacji z 1993 r., w której Chełpa nawiązał do kwestionariusza diagnozowania klimatu organizacyjnego zaproponowanego przez Kolba w latach 70., będącego zmodyfikowaną wersją narzędzia Litwina i Stringera, przetłumaczonego na język polski w 1984 r. przez Kożusznik i Jezierskiego (Chełpa 1993). Jako jeden z pierwszych polskich badaczy klimatu organizacyjnego zwrócił uwagę na potrzebę walidacji i oszacowania wskaźników psychometrycznych pod kątem adaptacji do polskich warunków. Klimat organizacyjny w omawianej publikacji został zdefiniowany przez badacza jako postrzegana przez pracowników sytuacja organizacyjna wynikająca z procesu interakcji zachodzącej między nimi a organizacją. Badanie walidacyjne Chełpa przeprowadził w 1992 r. w Pracowni Badań Psychologicznych w Lubinie na grupie 100 mężczyzn w zawodzie górnika w wieku 20-59 lat.

W kolejnej publikacji z roku 1996 Chełpa przedstawił rozważania nad uwarunkowaniami klimatu organizacyjnego i jego zależności od sytuacyjnych i personalnych czynników (Chełpa 1996). Badacz zwrócił uwagę na niejednolitość rozumienia klimatu organizacyjnego i kontrowersji w konceptualizacji pojęć klimatu i kultury, w związku z czym zaproponował, żeby kojarzyć klimat $z$ postrzeganiem kultury $i$ jej poznawczą reinterpretacją dokonywaną przez pracowników, tworzącą w ich umyślnie względnie trwały obraz rzeczywistości zawodowej. Powyższa interpretacja sugeruje odmienność „obiektywnej” kultury od „subiektywnego" klimatu. Ważnym kierunkiem poruszanym we wskazanej publikacji była próba dookreślenia i uporządkowania czynników determinujących klimat organizacyjny związanych z cechami osobowościowymi pracowników i uwarunkowaniami środowiskowymi pracy. W dalszej części artykułu polski badacz przywołał sygnalizowane wcześniej badania na grupie górników z Lubina, przeprowadzone z wykorzystaniem zmodyfikowanego przez siebie kwestionariusza Kolba, podkreślając traktowanie klimatu jako zmiennej zależnej - poznawczej reprezentacji rzeczywistości zawodowej. Natomiast analizowane zmienne osobowościowe niespecyficzne (neurotyzm, gotowość do obrony osobistych praw), zmienne osobowościowe specyficzne (motywy wykonywania pracy, rola zawodowa, aspiracje zawodowe, poczucie podmiotowości pracy) i zmienne środowiskowe (prestiz społeczny zawodu, prestiż zakładowy stanowiska, wynagrodzenie, pewność zatrudnienia, możliwość awansowania, przynależność do związku zawodowego) rozpatrywane były jako zmienne niezależne. Wyniki badań wykazały, że wyższy poziom neurotyczności powiązany był z klimatem autokratycznym, natomiast większa gotowość do obrony osobistych praw i interesów korespondowała z klimatem wspierającym, co Chełpa zinterpretował jako uzależnienie występowania klimatu wpierającego od dojrzałości osobowościowej górników. Z kolei wysoki poziom aspiracji miał pozytywne odniesienie względem klimatu autokratycznego. Nie odnotowano ważniejszych zależności między wiekiem, wykształceniem czy stażem pracy górników. W kontekście czynników środowiskowych badacz zauważył wpływ społecznego prestiżu i prestiż zajmowanego w firmie stanowiska na poziom klimatu wspierającego, wyciągając wniosek, że postrzeganie przez pracowników środowiska pracy jako prestiżowego, dającego pewność zatrudnienia i możliwości awansu jest powiązane ze wspierającym typem klimatu organizacyjnego. Badania potwierdziły również przyjęte wcześniej tezy o zależnościach między podmiotowością 
i klimatem wspierającym oraz alienacją i klimatem autokratycznym. Na tej podstawie Chełpa formułuje kilka ciekawych wniosków: (1) wspierający klimat organizacyjny jest warunkowany cechami osobowościowymi pracowników powiązanymi z rozwojem zawodowym, (2) występują silne zależności między wysokim poziomem aspiracji i klimatem autokratycznym - co może oznaczać brak wspierania, wzmacniania i popierania przez współpracowników i kierowników tych uczestników organizacji, którzy mieli wysokie aspiracje, (3) ważnym wyznacznikiem klimatu jest zgodność wykonywanej pracy z wyuczonym zawodem i (4) charakter i poziom klimatu organizacyjnego w większym stopniu kształtowany jest przez czynniki osobowościowe niż przez czynniki środowiska zawodowego - co dla praktyki zarządzania można traktować jako zalecenie dbałości o rozwój zawodowy i profesjonalny nie tylko w odniesieniu do kadry kierowniczej, ale również grup zawodowych. Prawdopodobnie prace Chełpy nad klimatem organizacyjnym trwałyby nadal, gdyby nie przedwczesna śmierć polskiego badacza w 2007 r.

Inna polska badaczka z pierwszej połowy lat 90., Irena Pufal-Struzik, charakteryzując konstrukt klimatu i odwołując się między innymi do dorobku Lewina, Parygina, Amdersona i Ekvalla, określiła to zjawisko jako: pobudzające bądź hamujące czynniki warunków pracy zapewniane przez organizacje; dominujący i specyficzny dla danego zespołu nastrój i nastawienie, przejawiające się $\mathrm{w}$ ustosunkowaniu do warunków pracy, wykonywanych czynności współpracowników i samego siebie czy też nastrój dominujący w zespole, względnie trwały, przejawiający się zarówno we wzajemnych stosunkach interpersonalnych, a także stosunku do wspólnego zadania (Pufal-Struzik 1993). Zalecanym przez badaczkę typem klimatu jest klimat oparty na motywacji osiągnięć, mający swoje źródło w samej pracy, umożliwiający zaspokojenie podstawowych potrzeb pracowników, promujący samodzielność i inicjatywę. We wskazanym opracowaniu przywołano wyniki szeregu badań nad rolą klimatu w różnych obszarach i procesach organizacji, jednakże najwyraźniej wyeksponowano większe możliwości pozytywnego oddziaływania na twórczość, kreatywność $i$ innowacje. W ostatniej części publikacji opisano wyniki badań przeprowadzonych w dwóch większych zakładach w Kielcach na łącznej grupie 120 racjonalizatorów i wynalazców pracujących zespołowo. $\mathbf{Z}$ przeprowadzonych badań wynikało, że największy wpływ na inicjatywę zespołowej pracy racjonalizatorskiej miała potrzeba rozwiązania ważnego problemu technicznego bądź organizatorskiego. Zaledwie $48 \%$ badanych potwierdziło odczucie satysfakcji z tytułu efektów własnej pracy. Negatywnie ankietowani wypowiedzieli się także o praktyce dopisywania w charakterze współautora innych osób celem zwiększenia możliwości i przyspieszenia realizacji projektu. Dodatkowymi problemami zgłoszonymi przez respondentów były m.in.: niedostateczna baza maszynowa i materiałowa, brak funduszy, niechęć i zazdrość współpracowników, niedostatki w procedurze zgłaszania projektów i nadmierna biurokratyzacja.

Kolejnym polskim badaczem klimatu z lat 90. jest Arkadiusz Potocki, który w 1992 r. zdefiniował klimat jako charakterystyczny dla danego przedsiębiorstwa zespół norm warunkujący zachowanie pracowników, wynikający zarówno z obiektywnie funkcjonujących procesów organizacyjnych, jak i subiektywnych odczuć pracowniczych z nimi związanych. Oba te czynniki nakładają się na siebie i wyznaczają ramy postępowania pracowników w danej organizacji (Potocki 1992). W 1996 r. Potocki przedstawił rozważania nad kształtowaniem klimatu innowacyjno-partycypacyjnego w organizacji 
(Potocki 1996). Połączenie wątków innowacyjności i partycypacji uzasadnił zamiarem podjęcia próby metodologicznej w kontekście humanizacji pracy, podzielonej na etapy: rozpoznania, zbierania informacji, diagnozy, projektowania i wdrożenia. Na pierwszym etapie następuje identyfikacja idealnego zarządzania innowacyjno-partycypacyjnego. Drugi etap w odniesieniu do informacji wewnętrznych obejmuje określenie obecnie panującego klimatu w kontekście jego determinant i skutków, które może być przeprowadzone $z$ wykorzystaniem badań ankietowych. Etap trzeci wiąże się z oszacowaniem możliwości stosowania nowego typu klimatu innowacyjno-partycypacyjnego. Potocki szczególnie podkreślił potrzebę dokładnego przeanalizowania takich czynników, jak m.in.: ocena obecnego klimatu pod kątem stymulowania innowacyjności, partycypacja i wspieranie rozwoju pracowniczego, nagradzanie i promowanie innowacyjności, sprawność komunikacji, systemy ocen pracowników i wdrażanych innowacji czy też otwartość i skłonność do ryzyka pracowników i kierownictwa organizacji. Zgodnie z propozycjami przywoływanego badacza kolejnym etapem jest identyfikacja potencjalnych barier wdrożenia klimatu innowacyjno-partycypacyjnego, a następnie przekazanie pracownikom informacji o zamierzeniach organizacji dotyczących nowej koncepcji klimatu w celu pozyskania ich jako podmiotów wspierających i wzmacniających cały proces. Istotnym czynnikiem wzmacniającym powinna być również dbałość organizacji o efektywne wykorzystanie posiadanych kwalifikacji i rozwoju zawodowego pracowników, a także zapewnienie zespołowości prac i sprawnej komunikacji. Według Potockiego wdrożenie, jako ostatni etap opisywanego procesu, nie ma charakteru jednorazowego i może trwać przez dłuższy okres, a wśród potencjalnych czynności, które są zalecane w tej fazie, wymienit: opracowanie instrukcji, ustalenie harmonogramu wdrożenia, zastosowanie wybranych metod wspomagania nowego typu klimatu, a także obserwację funkcjonowania organizacji po wdrożeniu i usuwanie ewentualnych przeszkód. Wątek klimatu innowacyjno-partycypacyjnego Potocki przedstawił również $w$ kolejnych swoich publikacjach (Potocki, Mikuła 1997; Potocki 1998).

Pod koniec lat 90. wyróżniła się publikacja Władysława Paluchowskiego poświęcona problematyce klimatu organizacyjnego (Paluchowski 1998). Badacz przypomniał $w$ niej o silnym zainteresowaniu tematyką kultury organizacyjnej w latach 80. Dookreślając sposób jej rozumienia, przywołał koncepcje Scheina i Adlera oraz wskazał powiązania między kulturą ogólną a kulturą organizacji w kontekście aspektów ekonomicznych, społecznych i politycznych. W ocenie Paluchowskiego, w latach 80. enigmatyczna konstrukcja kultury organizacyjnej, o niejasnej treści, zdominowała wątek klimatu organizacyjnego, przyczyniając się do problemów i kontrowersji związanych z właściwą konceptualizacją tych dwóch zagadnień, dookreśleniem zależności $i$ granic między nimi, a w niektórych przypadkach także utożsamianiem opisywanych kategorii. Niejasności i wieloznaczności z tym związane widoczne były nie tylko w publikacjach z lat 80., ale również w publikacjach kolejnego dziesięciolecia, a w rzeczywistości występują do czasów współczesnych. Zdaniem Paluchowskiego skutkiem-efektem kultury przedsiębiorstwa może być morale organizacyjne, reprezentujące postawę pracowników wobec całej organizacji i jej specyficznych czynników, takich jak kierownictwo, współpracownicy, system wzmocnień czy atmosfera panująca wśród pracowników. Badacz przywołał również te propozycje rozumienia kultury, w których 
naukowcy wskazują na odczucia pracownicze w stosunku do niej, które można utożsamiać z problematyką klimatu. Ostatecznie Paluchowski scharakteryzował klimat jako jeden z wewnętrznych czynników organizacji wpływający na jej skuteczność, efektywność i sprawność menedżerską, który komplementarnie z kulturą opisuje wewnątrzorganizacyjne czynniki motywacyjne. Definicja klimatu przytoczona przez badacza nawiązywała do propozycji Jamesa, Jonesa, Don Hellriegela i Slocuma. Badacz zaproponował również systematykę zagadnień związanych z klimatem z podziałem na klimat organizacyjny (charakterystyczny dla danej organizacji zespół zjawisk organizacyjno-społecznych), klimat informacyjny (odnoszący się do zjawisk komunikacyjnych w organizacji) oraz klimat psychologiczny (odnoszący się do indywidualnych postaw). Wskazane typy klimatów kształtują się pod wpływem cech rynkowych (zewnętrznych), kulturowych i organizacyjnych (wewnętrznych) przedsiębiorstwa, działających w dłuższym czasie, oraz wpływają blokująco lub facylitująco na działania pracowników. Ponadto Paluchowski wymienia i opisuje najważniejsze czynniki (składniki) klimatu organizacyjnego, do których zalicza klarowoność (celów, struktur, procedur), odpowiedzialność i delegowanie kompetencji (podział władzy, delegowanie uprawnień), adekwatność systemu oceniania, sposoby motywowania i politykę personalną, relacje praca-wynagrodzenie, akceptowany poziom ryzyka i prawa do błędu, rodzaj i poziom standardów wykonania pracy, styl zarządzania oraz potencjalne ograniczenia i bariery. W dalszej części publikacji Paluchowski przedstawił zweryfikowany autorski kwestionariusz, wypracowany na bazie ówczesnych rozwiązań innych badaczy i dostępnej literatury, zaprezentowany w trakcie konferencji, złożony z 7 wymiarów i 47 pozycji ${ }^{3}$. Wśród wymiarów klimatu organizacyjnego badacz uwzględnił: (1) pozytywną relację bezpośredni przełożony-podwładny, (2) tolerowanie ryzyka i konfliktów, (3) poczucie osamotnienia, (4) dobry dostęp do informacji, (5) identyfikację z zespołem pracowniczym, (6) punitywną rywalizację, 7) ogólną pozytywną postawę wobec organizacji. Próbką badawczą do weryfikacji zaproponowanego kwestionariusza była grupa 407 pracowników prywatnych i państwowych przedsiębiorstw produkcyjnych oraz jednostek budżetowych, poddanych badaniu w latach 1994-1996. Przeprowadzone przez Paluchowskiego badania na grupie 407 pracowników nie obejmowały jednak kompletnej procedury walidacyjnej i w wymienionej publikacji wskazany autor przedstawił tylko wyniki analizy czynnikowej struktury wewnętrznej testu z wykorzystaniem rotacji Varimax. Propozycja kwestionariusza nie zawiera również zasad interpretowania wyników testów ani przedziałów oceniania.

\section{Konkluzje i refleksje odnoszące się do analizowanego dorobku naukowego związanego z klimatem organizacyjnym w przyjętym przedziale czasowym}

Polski dorobek naukowy przedstawiony w publikacjach do końca lat 90. w zakresie problematyki klimatu organizacyjnego składania autora do kilku ważnych wniosków. Po pierwsze, zainteresowanie problematyką klimatu

\footnotetext{
3 Autorski charakter kwestionariusza Władysław Paluchowski potwierdził w trakcie konsultacji w dniu 16.11.2013 r. - w omawianej publikacji Władysława Paluchowskiego nie ma jednoznacznej informacji, która wskazuje, kto jest autorem kwestionariusza. W tym celu autor niniejszej publikacji w trakcie konsultacji zapytał Władysława Paluchowskiego, czy kwestionariusz jest autorstwa wspomnianego badacza.
} 
organizacyjnego w polskiej literaturze oraz związane z tym próby konceptualizacji czy pierwszych badań w zakresie tej problematyki pojawiły się stosunkowo późno. Przytaczana pozycja Dobrzyńskiego pochodzi z końca lat 70., zatem blisko 40 lat później w stosunku do zainteresowania zjawiskiem klimatu przez Lewina, White'a i Lippita, a także prawie 25 lat od przedstawienia zagadnienia klimatu organizacyjnego przez Cornella i niemal pod koniec kluczowego okresu zainteresowań i rozwojem kategorią klimatu organizacyjnego, przypadającego na lata 60. i częściowo 70. Jako główną przyczynę tego opóźnienia w naukowym zainteresowaniu problematyką klimatu można z pewnością wskazać ograniczenia w dostępie do źródeł zagranicznych o charakterze językowym i informatycznym, które były szczególnie odczuwalne w Polsce w latach 70. i 80. Potwierdza to stosunkowo niewielka ilość przytaczanych zagranicznych publikacji względem całego dorobku naukowego, który powstał do roku 1977. I chociaż, jak sugerują artykuły Sokołowskiego i Barana, zjawisko klimatu (organizacyjnego bądź społecznego) było już względnie powszechnie stosowane w warunkach polskich, to jednak nie zmienia to faktu, że naukowe zainteresowanie $w$ kontekście problemów organizacji i zarządzania pojawiło się stosunkowo późno. Praca Dobrzyńskiego ukazała się w zbliżonym okresie w stosunku do wyłonienia problematyki kultury organizacyjnej (1979) i chociaż polscy badacze odpowiednio szybciej zainteresowali się nową koncepcją kultury niż miało to miejsce w przypadku klimatu, to z drugiej strony rozpoznawanie dopiero problematyki klimatu organizacyjnego w zderzeniu z nową i cieszącą się dużym zainteresowaniem koncepcją kultury organizacyjnej przyczyniły się do kolejnych niejasności i braku klarowności w odniesieniu do klimatu organizacyjnego i jego relacji z kulturą w latach 80. Z kolei w obszarze badawczym klimatu w pierwszych polskich publikacjach da się zauważyć niedostatki metodyczne pomiaru i analizy klimatu wynikające $z$ utrudnień $w$ dostępie do oryginalnych zagranicznych narzędzi oraz zagranicznych publikacji. Kolejnym czynnikiem utrudniającym bądź ograniczającym prowadzenie pierwszych badań empirycznych był ich interdyscyplinarny charakter i komplikacje związane z budowaniem zróżnicowanych zespołów badawczych, na co dodatkowo nakładała się wcześniej wskazana kwestia niewielkiego zainteresowania polskich badaczy naukowych klimatem organizacyjnym i niedocenianiem tej problematyki. Po wtóre, pierwsza faza zainteresowań problematyką klimatu organizacyjnego w Polsce charakteryzuje się niewielką ilością publikacji naukowych, a same dociekania związane z klimatem mają charakter powierzchowny, zaczepny i fragmentaryczny. Z lektury piśmiennictwa wynika, że do końca lat 80. nie ukazała się żadna książka naukowa, w której tytuł zawierałby termin „klimat organizacyjny”, a dorobek polskich badaczy sprowadza się w istocie do kilku- kilkunastostronicowych artykułów naukowych, których zresztą łączna liczba we wskazanym okresie nie przekroczyła 10 pozycji.

Po trzecie, w pierwszych polskich publikacjach, mimo podejmowanych prób wyodrębnienia i scharakteryzowania kategorii klimatu organizacyjnego, w niewielkim zakresie opisano zależności i powiązania tego pojęcia z takimi kategoriami współzależnymi, jak choćby satysfakcja z pracy czy kultura organizacyjna, chociaż zagraniczny dorobek naukowy w przyjętym okresie (do końca lat 90.) względnie wyraźnie obejmował te kwestie. Niedostatki w opisywanym zakresie skutkowały nierzadko zamiennym stosowaniem wskazanych pojęć, co prowadziło w rezultacie do niejasności i wieloznaczności rozważań $w$ polskim dorobku 
naukowym powiązanym z tym obszarem. Te mankamenty występują w niektórych publikacjach do dzisiaj.

Po czwarte, autor odnosi wrażenie, że w kolejnych polskich publikacjach w stosunkowo w niewielkim zakresie aktualizowano i pogłębiano zagraniczny dorobek naukowy w dziedzinie problematyki klimatu organizacyjnego - ważniejsze nazwiska zagranicznych autorów, kojarzonych obecnie z rozwojem tej koncepcji, pojawiają się w pierwszych polskich publikacjach Dobrzyńskiego, Bratnickiego czy Wyciślaka, natomiast w kolejnych pozycjach nie wzbogacano znacząco zarówno bazy źródłowej kluczowych badaczy naukowych klimatu, jak również ich ówczesnych osiągnięć. Pierwsze polskie publikacje, szczególnie Wyciślaka i Dobrzyńskiego, dosyć długo traktowano w kolejnych latach jako swoistą wyrocznię w postrzeganiu i wyjaśnianiu klimatu organizacyjnego lub jako jedyną i zamkniętą bazę odniesień w zakresie badania klimatu organizacyjnego. W kolejnych latach w niewielkim zakresie podejmowano próby samodzielnej konceptualizacji klimatu organizacyjnego bądź jej modyfikacji czy rozwoju, jak również w niewielkim stopniu systematyzowano dorobek teoretyczny, metodyczny i empiryczny w podjętym temacie. Doprowadziło to w efekcie do powstania w kolejnych latach zjawiska „błędnego koła" w dociekaniach naukowych związanych z klimatem organizacyjnym, czego odzwierciedleniem było m.in. powoływanie się na te same i nierzadko przedawnione źródła naukowe - polskie i zagraniczne.

Po piąte, we wczesnych polskich publikacjach poruszana problematyka obejmuje takie obszary, jak istota klimatu organizacyjnego, składniki klimatu organizacyjnego, jego typologia, czynniki kształtujące klimat, znaczenie klimatu organizacyjnego, różne konteksty zarządzania i organizacji, a także takie aspekty, jak metodyka diagnozy klimatu, adaptacja i walidacja czy metodyka wdrożenia pożądanego klimatu (np. propozycje Potockiego). Wskazane wątki obejmują więc różne elementy dorobku teoretycznego, metodycznego i empirycznego, przy czym wyraźna większość poruszanych tematów i pozycji z nimi związanych kojarzona jest z dorobkiem teoretycznym. Należy jednak w tym miejscu jeszcze raz podkreślić znikomą ilość polskich artykułów poświęconych wyłącznie problematyce klimatu, jak również odczuwalny brak tendencji do pogłębiania i aktualizowania polskiego dorobku do końca lat 90. proporcjonalnie do rosnącego dorobku zagranicznego. Ówczesne próby konceptualizacji klimatu organizacyjnego miały w większości charakter punktowy i opierały się na stosunkowo wąskiej bazie źródłowej.

Po szóste, w analizowanym dorobku polskim zauważalny jest brak ciągłości zainteresowań i badań związanych z klimatem organizacyjnym, a wśród nielicznych wyjątków można wskazać takich badaczy jak Dobrzyński, Bratnicki, Chełpa czy Potocki, chociaż nawet $w$ ich przypadku łączna liczba publikacji poświęconych bezpośrednio problematyce klimatu organizacyjnego w odniesieniu do każdego z nich nie przekracza w opisywanym okresie 5 pozycji, a przeprowadzone przez autora niniejszej publikacji studia literaturowe dotyczące kolejnego okresu (lata 2000-2014) nie wykazały, żeby przywoływani autorzy zaczęli w większym stopniu interesować się i publikować prace naukowe powiązane z problematyką klimatu organizacyjnego. Po siódme, polski dorobek z analizowanego okresu był bardzo rzadko wskazywany w liczących się publikacjach zagranicznych, a więc nasz rodzimy wkład w światowy dorobek naukowy w opisywanym obszarze był w tym czasie bardzo znikomy. 


\section{Zakończenie}

W opracowaniu scharakteryzowano polski dorobek naukowy w zakresie zjawiska klimatu organizacyjnego w okresie 1977-1999. Autor podjął próbę ewolucji i systematyzacji naszego rodzimego dorobku w zakresie podmiotowym i przedmiotowym. Ten ostatni obejmował przede wszystkim wątki teoretyczne, ale po części także metodyczne i empiryczne. Omówienie dorobku polskiego poprzedzają rozważania poświęcone genezie i ewolucji naukowych zainteresowań klimatem organizacyjnym w piśmiennictwie zagranicznym w latach 50., 60. i 70. oraz kojarzone z takimi nazwiskami, jak np. Lewin, White i Lippit czy Cornell. Na tym tle przybliżono dorobek polski, wyodrębniając dorobek w latach 70., 80. i 90. Wśród najważniejszych i wyróżniających się polskich badaczy klimatu organizacyjnego wskazano Dobrzyńskiego, Bratnickiego, Chełpę i Potockiego. W opracowaniu przeprowadzono analizę dorobku polskiego w analizowanym okresie

\section{Bibliografia}

Adamiecki K. (1985), O nauce organizacji. Wybór pism, Warszawa, PWE.

Baran J. (1983), Stosunki międzyludzkie i klimat społeczny w socjalistycznym zakładzie pracy, "Socjologia Pracy", nr 1, Wyższa Szkoła Nauk Społecznych przy KC PZPR, Instytut Filozofii, Socjologii i Religioznawstwa, Warszawa.

Bratnicki M., Kryś R., Stachowicz J. (1988), Kultura organizacyjna przedsiębiorstw, Wrocław, Polska Akademia Nauk, Ossolineum.

Bratnicki M., Wyciślak W. (1980), Klimat organizacyjny. Pojęcie, mierzenie, i na tej podstawie sformułowano najważniejsze konkluzje i wnioski, z których na uwagę zasługują następujące: dosyć późne zainicjowanie zainteresowań związanych z klimatem, niewielki stopień zainteresowań mierzony liczbą publikacji i ciągłością badań naukowych, uboczny charakter problematyki klimatu i nierzadko powierzchowność rozważań, a także dosyć duże opóźnienia w zgłębianiu i systematyzowaniu oraz rozwijaniu dorobku zagranicznego. W opinii autora problematyka klimatu organizacyjnego wciąż wymaga kompleksowego pogłębienia i systematyzacji, także $\mathrm{w}$ perspektywie historycznej. Ma to swoje uzasadnienie teoretyczne, metodyczne i praktyczne. Przesądza o tym także uniwersalność i ponadczasowość tego zjawiska oraz jego funkcjonalność w kontekście zarządzania firmą. Prezentowane opracowanie autor traktuje jako pierwszy krok w tym kierunku. Z pewnością celem kolejnej publikacji będzie uzupełnienie dorobku naukowego w podjętym temacie o dorobek polski obejmujący lata 2000-2014.

badania i diagnoza, „Prakseologia”, nr 4 (76).

Burnside R.M., Amabile T.M., Gryskiewicz S.S. (1988), Assesing Organizational Climates for Creativity and Innovation. Methodological Review of Large Company Audits, [w:] New Directions in Creative and Innovative Management, ed. Y. lijri, R.L. Kuhn, Cambridge, MA: Ballinger Publishing Co.

Chełpa S. (1992), Podmiotowość pracowników a klimat i efektywność organizacji, „Organizacja i Zarządzanie. Prace Naukowe Akademii Ekonomicznej we Wrocławiu", nr 625. 
Chełpa S. (1996), Uwarunkowania klimatu organizacyjnego (studium empiryczne), „Organizacja i Kierowanie”, Nr 1 (83).

Chełpa S. (1993), Walidacja kwestionariusza klimatu organizacyjnego Kolba, „Przegląd Psychologiczny”, t. XXXVI, nr 3.

Cornel F.G. (1955), Socially Perspective Administration, "The Phi Delta Kappan", vol. 36, no. 6 .

Dobrzyński M. (1977), Klimat organizacyjny jako wyznacznik stylu zarządzania, „Przegląd Organizacji”, nr 1 (444).

Dobrzyński M. (1981), Klimat organizacyjny jako regulator zachowania się ludzi, „Organizacja i Kierowanie”, nr 1 (23), Warszawa-Łódź, PWN.

Kożusznik B., Jezierski T. (1984), Psychologia doskonalenia zespołów (wybrane zagadnienia), Katowice, Wydawnictwo Uniwersytetu Śląskiego.

Lewin K., Lippitt R., White R.K. (1939), Patterns of Agressive Behaviour in Experimentally Created "Social Climates", "Journal of Social Psychology", vol. 10.

Martyniak Z. (1996), Organizacja i zarządzanie. 60 problemów teorii i praktyki, Kluczbork, Wydawnictwo Antykwa.

Paluchowski W.J. (1998), Klimat organizacyjny i jego pomiar, [w: ]
Psychologiczne wyznaczniki sukcesu w zarządzaniu, red. S. Witkowski, Prace Psychologiczne Uniwersytetu Wrocławskiego XLVTT, t. IV.

Potocki A. (1992), Wybrane metody humanizacji pracy, Wrocław, Ossolineum.

Potocki A. (1996), Metodyka kształtowania innowacyjno-partycypacyjnego klimatu organizacyjnego, „Humanizacja Pracy".

Potocki A. (1998), Wdrożenia innowacyjno-partycypacyjnego klimatu organizacyjnego, „Humanizacja Pracy”, nr $5 / 6$.

Potocki A., Mikuła B. (1997), Metody zarządzania innowacyjno-partycypacyjnego, Kraków, Oficyna Wydawnicza Antykwa.

Pufal-Struzik I. (1993), Atmosfera i klimat w organizacji jako czynniki stymulujące lub hamujące efektywność twórczych zachowań pracowników, [w:] Myśl psychologiczna w Polsce Odrodzonej, red. A. Bańka, R. Derbis, Poznań.

Sokołowski L. (1967), Wpływ struktury gramatycznej tekstu na jego rozumienie, „Zeszyty Prasoznawcze”, nr 4 (34), Kraków.

Wyciślak M. (1980), Miejsce i rola klimatu organizacyjnego w funkcjonowaniu organizacji, „Organizacja i Kierowanie", nr 1 (19).

\title{
The Beginnings of Interest in Organizational Climate Issues in Polish Scientific Literature
}

\begin{abstract}
The paper contains a chronological review of the beginnings of Polish scientific achievements in organizational climate construct. The author presents research findings of the first Polish researchers of this concept, characterized the proposed ideas, definitions, typologies, dimensions and items, as well as the direction of first Polish research, including their scope, findings and achie-
\end{abstract}


ved results. Next, the author summarizes and systematizes the achievements of the first Polish researchers, confronts this developments with foreign ones and then points out the potential directions of reflections and research in organizational climate.

Keywords: organizational climate, social climate, types of organizational climate types, dimensions and components of organizational climate, factors affecting organizational climate 
